\title{
METHODS OF NAMING COMMERCIAL OBJECTS, ENTERPRISES, COMPANIES IN UZBEK LANGUAGE
}

\section{Prof. Durdona Lutfullayeva}

Doctor Of Philology, Professor. Institute Of Uzbek Language, Literature And Folklore Of The Academy Of Sciences Of The Republic Of Uzbekistan

\section{ABSTRACT}

In this article, the criteria for creating a name in the Uzbek language, the requirements for creating and choosing a name, the names were given to commercial objects, enterprises, firms, consumer goods in our country are analyzed and critically studied. Problems were addressed and they identified methods of naming.

KEYWORDS: - Naming practice, naming technology, linguistics, naming technology, entrepreneurnominator, naming techniques.

\section{INTRODUCTION}

Each language has principles for naming a particular object and ways to create a new name based on these principles. In the Uzbek language, names are formed in different ways, depending on certain thematic groups, following certain principles.

As names are formed by language speakers, it is natural for them to be influenced by personality factors. This shows that the principles of naming in different languages differ depending on the human factor.

\section{THE MAIN RESULTS AND FINDINGS}

In Uzbek linguistics, linguistic principles have been identified that play an important role in the formation of various thematic groups, including silkworm breeding, weaving, food names, and technical terms [1]. In particular, S. Ibragimov notes that the terms of silkworm breeding in Fergana dialects are based on the following principles:

1) the principle of analogy;

2) the principle of adaptation;

3) the principle of proportionality;

4) the principle of naming according to the material; 
CURRENT RESEARCH JOURNAL OF PHILOLOGICAL SCIENCES 2(12):

84-89, December 2021

DOI: https://doi.org/10.37547/philological-crjps-02-12-18

ISSN 2767-3758

(C)2021 Master Journals

Crossref do

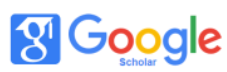

Accepted10 ${ }^{\text {th }}$ December, 2021 \& Published 15 th December, 2021

5) the principle of naming by function;

6) the principle of naming according to place;

7) the principle of naming according to appearance and appearance;

8) the principle of naming by voice;

9) the principle of naming by size;

10) the principle of naming in terms of process and action;

11) the principle of naming people based on their gender and sexual characteristics;

12) the principle of naming by age;

13) the principle of naming in order;

14) the principle of naming in connection with tradition;

15) the principle of naming in connection with mythical concepts and myths;

16) the principle of naming in connection with a historical event $[2,156]$.

It is clear that the Uzbek people, in creating the name, paid attention not only to the specifics of the object: shape, size, material, function, sound, etc., but also to the gender, age and customs of the people.

Certain principles and naming methods are also used to create names for business entities, firms and enterprises. Sh. Ergashkhojayeva notes the need to follow the following principles when creating a new name for consumer goods: 1 ) the use of creative methods of research; 2) transformation (change) of any known name until there are no legal objections to the new name; 3 ) formation of a new name as a reflection of a competing brand name; 4) use any popular name to add it to a new brand name $[3,44]$.

Apparently, there are objects of business activity, specific principles of naming consumer goods and methods of naming. The analysis of such names shows that in our country, in naming the products of nominee entrepreneurs, the following methods of naming were used:
I. Select a lexical unit for a name from its own language (or another language) resource.

II. Create a name in different ways based on the internal capabilities of the Uzbek language.

The following naming conventions were used to select the lexical units available in the language for the name:

1 The method of naming people by name. Entrepreneurs often name the object of production, consumer services, trade, consumer goods themselves or their parents, grandparents, children. Of course, such names do not give an initial idea of the object. Although they do not carry personal information, they do indicate to whom the object belongs. In choosing a name in this way, the entrepreneur aims to introduce himself to the consumer. For example: "AHMAD" (cafe, Tashkent), "ABDURASHID OTA" (teahouse, Tashkent), "IBRAHIM BEK" (restaurant, Tashkent), "ISRAIL HOJI OTA" (wedding, Tashkent).

Sometimes people's names are given together with the English words "Palace" and "City". Of course, naming in this way does not comply with the norms of the Uzbek literary language. For example, MARHABO PALACE (hotel, Tashkent), BOBUR CITY (hotel, Tashkent).

2. Method of naming with place names. The use of place names in the naming of business objects and consumer goods is also common. There are two ways to do this: 1) the objects of production, consumer services, trade are given the name of the area where it is located, the place of manufacture of the product. For example, "KUSHBEGI" (hotel, Tashkent, Kushbegi Street); 2) The object of trade and production is named after the largest developed cities and countries in the world, and this name is intended to arouse interest in the object, to attract the attention of consumers. For example: "NEW YORK" (hotel, Tashkent), "BODRUM" (cafe, Tashkent), "XIVA" (hotel, Tashkent), "SEUL" 
CURRENT RESEARCH JOURNAL OF PHILOLOGICAL SCIENCES 2(12):

84-89, December 2021

DOI: https://doi.org/10.37547/philological-crjps-02-12-18

ISSN 2767-3758

(C)2021 Master Journals

Crossref do

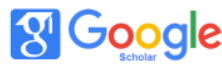

Accepted10 ${ }^{\text {th }}$ December, 2021 \& Published 15 th December, 2021

\section{(restaurant, Tashkent), “ASIA TASHKENT" (restaurant, Tashkent) city).}

The choice of names for the name is based on the principle of relevance in the selection of area names. Naming a business object in this way creates an associative view of the area where the object is located. For example, a hotel on Shohjahon Street in the Yakkasaray district of Tashkent is named after this street ("SHOHJAHON"), which is directly reminiscent of a hotel. Similarly, a hotel in the Yakkasaray district of Tashkent, Karakum, is named after him. Or the name of the shopping center "ORIKZOR" is associated with the name of the area where the object is located - Tashkent city, Uchtepa district, Urikzor massif. The choice of names in this way takes into account the rapid recovery of the object by name in the memory of language owners.

3. How to name a place and people. The names given to products of the production, consumer services, trade, products consist of the name of the entrepreneur or his parents, the name of the child and the area where the object is located, the place of production. While such names do not provide information about the nature of the object or what type of activity it is engaged in, they do serve to indicate to whom it belongs and where it is located. For example: "BOBUR-SHER-OKTOSH" (private enterprise, Tashkent region).

4. The method of naming "famous names". The name of the object of production, consumer services, trade is sometimes the name of famous people, literary heroes, cultural objects known worldwide or within a certain nation. Such names are precedent names and are popular names in the linguistic memory of language owners [4, 53]. An important aspect of precedent names is that when they are used in speech, they not only express a specific person, a reality, a city, an organization, etc., but also a specific cultural symbol, a symbol of a particular event [5,4]. For example: "TOJMAHAL" (restaurant, Tashkent), "SIM SIM" (cafe, Tashkent), "RAJ KAPUR" (restaurant, Tashkent), "HEMINGUAY" (restaurant-bar, Tashkent). RAJ KAPUR, HEMINGUEY are the names of world-famous people, TOJMAHAL is the name of an ancient architectural monument of the Baburi dynasty in India, and SIM SIM is the name of the famous Arabic fairy tale Alibobo and Qir. means "magic" used in "robber." The purpose is to attract the consumer in the selection of precedent units as the name for such objects of business activity.

How to name in foreign words. In recent years, the choice of foreign words as a name for production, consumer services, trade, products has become more common in our country. However, it should be noted that such names do not comply with the principles of naming in Uzbek. For example, CRAFERS (candy store, Tashkent), NORMA (limited liability company, Tashkent), TROYKA (barrestaurant, Tashkent) and others. Such names also appear as phrases: "GRUZINSKIY DVORIK" (restaurant, Tashkent), "U BABUSHKI” (restaurant, Tashkent), "KOKANDSKIY DVORIK" (restaurant, Tashkent), "GRAND” (ice cream, Tashkent city). We cover this issue in a separate paragraph below.

Method with associative units. Names for business entities, firms, enterprises, and consumer goods are sometimes chosen based on the entrepreneur's associative perceptions of his or her firm, organization, store, or product. For example, names such as "GUEST" (hotel, Tashkent), "MAZZA" (national cuisine restaurant, Tashkent), "ZIYOFAT" (restaurant, Tashkent), "TANTANA" (restaurant, Tashkent) are formed in this way.

It is known that in the memory of every Uzbek speaker, the word hotel restores the word guest; the word restaurant restores the word banquet, the word celebration. Alternatively, when we hear a combination of national dishes, the imagination of our delicious national dishes naturally brings to 
CURRENT RESEARCH JOURNAL OF PHILOLOGICAL SCIENCES 2(12):

84-89, December 2021

DOI: https://doi.org/10.37547/philological-crjps-02-12-18

ISSN 2767-3758

(C)2021 Master Journals

Crossref do

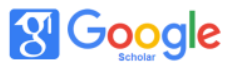

Accepted10 ${ }^{\text {th }}$ December, 2021 \& Published 15 th December, 2021

mind the lexeme of taste. This means that the hotel is called "GUEST" and the restaurant is called "MAZZA", "ZIYOFAT", "TANTANA".

The name of the restaurant "CHOY-POY" operating in the capital (Tashkent, Yakkasaray district) is also unique, reminiscent of the Uzbek table and national dishes.

How to name with ethno cultural words. In our country, words for production, consumer services, trade, or products are sometimes chosen as names denoting our national and cultural values. For example: "NAVRUZ" (hotel, Tashkent), "LAZGI" (restaurant, Tashkent), "DUTOR" (restaurant, Tashkent), "TANOVAR" (wedding, Tashkent), "TANDIR" (cafe, Tashkent city). Names like these do not give a clear idea of the object you're naming. However, because of their national and cultural context, they are remembered as well-known units. Sometimes the name is chosen for the names of famous literary heroes, movie heroes, who rose to the level of precedent units. The choice of such names for production, consumer services, trade or products also violates the criteria of accuracy. For example, the name "THREE GRAINS" given to a cafe in Tashkent is named after a famous Russian film.

Naming method with chapter names. In our country, the word spring is often chosen as a name for enterprises, firms, government agencies, some service facilities. For example: "BAHOR" (restaurant, Tashkent city), "BAHOR" (dance ensemble, Tashkent city), "BAHOR" (shopping center, Samarkand region) "BAHOR" (mahalla citizens' assembly, Syrdarya city), "BAHOR" (Preschool No. 11, Samarkand region). Of course, the name does not refer to spring, but to youth, beauty, renewal, and joy.

The method of naming food, fruit products. Manufacturing, consumer services, and retail outlets are sometimes given food names. For example: "GREEN TEA" (limited liability company), "ANOR" (cafe, Tashkent city), "ANJIR" (restaurant, Tashkent city), "IMBIR" (restaurant, Tashkent city), KISH-MISH "(Cafe, Tashkent), Although such names are familiar to Uzbek speakers, they do not accurately describe the object.

We based the naming method on the description. The principal focus of naming in this way is to describe the business activities carried out in the commercial object; the type of product, what we intended it for, and its natural properties. For example, the name of the private enterprise "KAMARBASTA BUKHGALTER" (Tashkent), which is engaged in accounting, is descriptive. They describe one teahouse in Tashkent as "MUHTASHAM". It is also clear that the name "GUARANTEE" given to the insurance company is a description of the company, referring to its warranty service. The names "HALOL USTA" (private homeowners 'association, Tashkent), "KHAIRLI KOMMUNALCHI" (private homeowners' association, Tashkent) are based on the same principle.

The naming method is based on the evaluation. When an entrepreneur chooses a name in this way, he focuses on evaluating the object of his production, glorifying his product, and raising it to the sky. For example, the name of the restaurant "TASANNO" in the capital, the name of the wedding "ALO" indicates the positive assessment of the entrepreneur to his restaurant, wedding. The name "HOSIYATLI KUT-BARAKA" for sour cream produced in the Almazar district of Tashkent also reflects the entrepreneur's assessment of his product.

Sometimes there are names that express gratitude and satisfaction with what is being done today. For example: "SHUKRONA" (national cuisine restaurant, 
CURRENT RESEARCH JOURNAL OF PHILOLOGICAL SCIENCES 2(12):

84-89, December 2021

DOI: https://doi.org/10.37547/philological-crjps-02-12-18

ISSN 2767-3758

(C2021 Master Journals

Crossref do

8 Google

Accepted10th December, 2021 \& Published 15 th December, 2021

Tashkent).

Desired-based naming method. The naming of a commercial object or consumer goods in this way takes into account the wishes of the person associated with the entrepreneurial activity. For example, "BAROKAT" (cafe, Tashkent), "NOVVOT" (teahouse), "SHOHSAROY" (restaurant, Tashkent). The name "BAROKAT" given to the cafe means that the nominee-entrepreneur wants this cafe to bless him. The naming of the teahouse as "NOVVOT" also suggests that the owner wants the teahouse to become a "sweet place".

Or the choice of the name "SHOHSAROY" suggests that the owner of the restaurant wanted the place to be like a palace of kings. This method also uses popular words and phrases (precedent units) to choose a name. For example: "LUCKY BIRD" (shop, Andijan).

\section{Conclusion}

Creating a name is not an easy task, it is a type of activity that requires creativity. There are certain requirements for nominees when creating a name. In particular, they must have a thorough knowledge of the norms of literary language, the ability to accurately and truthfully assess the impact of language, the ability to use language units in the formation of the name in an appropriate and appropriate manner, and, most importantly, the created name requires the ability to create effective communicative communication between producer and consumer, commercial product and buyer. This means that a name cannot be created by any language owner and that certain rules must be followed when creating a name.

There is another aspect to consider here. There are also legal aspects of creating a new name for the objects of business, firm, enterprise, consumer goods, it's brand. The choice of name is reflected in the Law of the Republic of Uzbekistan "On State Language", the Law "On Firm Names", the Law "On Trademarks, Service Marks and Appellations of Origin" requirements and standards must also be followed. In particular, Article 4 of the Law of the Republic of Uzbekistan "On Firm Names" specifies the absence of the following symbols in the name of the firm: 1) the official name of the state, the abbreviated or full name of an international, intergovernmental or non-governmental organization; 2) full or abbreviated name of a person who is historical or famous in the Republic of Uzbekistan, without permission issued in a prescribed manner; 3) fake or misleading information about the owner of the company name, its type of activity or the country of origin; 4) signs that contradict the interests of society, the principles of humanity and morality [6].

So, when naming business objects, enterprises, firms, consumer goods, it is common practice to choose from the words of our language and raise them to the level of a name. At the same time, there is a common way to create a new name using the internal capabilities of the Uzbek language.

\section{ReFERENCES}

1. Ibrohimov S. Professional vocabulary of Fergana dialects. - Tashkent: UzFA, 1959. - B. 157-168; Ikromova N. On the principles of naming dishes in Uzbek // Uzbek language and literature. - Tashkent. 1967. - №1. - B. 49-51; Tursunova T. Vocabulary of applied art of Uzbek language. - Tashkent: Fan, 1978. - B. 6971; Xudayarova M. Linguistic analysis of food names in Uzbek (based on materials from the territory of Karakalpakstan), - Tashkent, 2008.

2. Ibragimov S. Cited source. - B. 157-168.

3. Ergashxodjaeva Sh. Innovative marketing. Study guide. - Tashkent: TSU, Economics, 2014. 
CURRENT RESEARCH JOURNAL OF PHILOLOGICAL SCIENCES 2(12):

84-89, December 2021

DOI: https://doi.org/10.37547/philological-crjps-02-12-18

ISSN 2767-3758

(C)2021 Master Journals

crossref do) :810 Google

Accepted10th December, 2021 \& Published 15 th December, 2021

- B. 44. (p. 177)

4. Maslova V.A. Linguoculturology. - $\mathrm{M}$.: Academia, 2001. - p. 53.

5. Nakhimova E.A. Precedent names in mass communication. - Yekaterinburg: GOU VPO "Ural. state ped. un-t "; Institute of Social Education. 2007 .-- S. 4.

6. Law of the Republic of Uzbekistan "On Firm Names" //// https://nrm.uz/contentf?doc=311466_o\%E2\% $80 \% 98$

7. Lutfullaeva D., Saparniyazova M. Naming: The Technology of Creating a Name in the Language. Test Engineering and Management. November-December 2019. United States: Mattingley Publishing Co., Inc. P. 4183 - 4189.

8. Lutfullaeva D., Saparniyazova M., Davlatova R. Criteria for creating a name in the uzbek language// Journal of Critical Reviews. VOL 7, ISSUE 16, 2020. P.3142-3145.

9. Djafarov, B., \& Arifdjanov, Z. (2021). ISSUES IN SEMANTIC STUDY OF TURKIC LOANWORDS IN PERSIAN. Theoretical \& Applied Science, (6), 350-352.

10. Arifdjanov, Z. T. (2021). VARIANTS OF SIMPLE VERB خواسد تن. Theoretical \& Applied Science, (6), 418-420. 